\title{
KORUPSI DI CHINA: PERSPEKTIF SEJARAH
}

\author{
Oleh: Ririn Darini \\ Ilmu Sejarah FISE UNY
}

\begin{abstract}
Abstrak
Tulisan ini bertujuan untuk menjelaskan korupsi yang terjadi di China dari perspektif sejarah dengan melihat masalah dan dinamika pemberantasannya. Korupsi di China dapat ditelusuri sejak zaman kekaisaran dan sampai saat ini wabah korupsi terus berlangsung di China meskipun pemerintah gencar melaksanakan gerakan anti korupsi dengan memberikan sanksi hukuman yang berat seperti hukuman penjara seumur hidup dan bahkan hukuman mati. Korupsi di China sangat terkait dengan aspek politik, ketika korupsi melibatkan pejabat yang menduduki birokrasi. Para pejabat telah menyalahgunakan kekuasaannya untuk memperkaya diri melalui praktekpraktek korupsi. Korupsi di China juga sering dikaitkan dengan guanxi, budaya koneksi.
\end{abstract}

Kata kunci: Korupsi, China, Sejarah.

\section{A. Pendahuluan}

Ekonomi China yang tumbuh pesat memunculkan masalah-masalah baru bagi negeri tersebut. Beberapa permasalahan tersebut di antaranya kesenjangan pembangunan antara daerah pantai timur dan selatan dengan daerah tengah dan barat, jumlah pengangguran yang semakin besar, serta korupsi yang semakin meluas. Korupsi merupakan salah satu ancaman yang cukup besar bagi ekonomi China. Hal ini tercermin dari data yang disampaikan Ross Terril (dalam Taufik Adi Susilo, 2008:182), bahwa "satu persen penduduk China memiliki 40\% kemakmuran, sebagian di antaranya didapatkan melalui korupsi”.

Korupsi adalah penyalahgunaan wewenang untuk kepentingan pribadi. Pelaku korupsi pada umumnya adalah pejabat negara pemegang birokrasi dan dalam prakteknya biasanya melibatkan pihak lain. Dalil Lord Acton yang sangat terkenal terkait dengan korupsi yang melibatkan kekuasaan adalah "power tend to corrupt, absolute power corrupts absolutely". Alatas (dalam Endang Retnowati, 2006:139) mengidentifikasikan beberapa ciri korupsi, yaitu bahwa tindakan korupsi selalu melibatkan lebih dari satu orang, pada umumnya korupsi melibatkan keserbarahasiaan, melibatkan elemen kewajiban dan keuntungan timbal balik, setiap tindakan korupsi selalu berisi penipuan, pelaku korupsi menyelubungi perbuatannya dengan berlindung di balik pembenaran hukum, mereka yang terlibat menginginkan keputusan-keputusan yang tegas dan mereka yang mampu untuk memengaruhi keputusan-keputusan 
itu, korupsi melanggar tugas dan pertanggungjawaban dalam tatanan masyarakat, setiap bentuk korupsi adalah pengkhianatan kepercayaan, setiap bentuk korupsi melibatkan fungsi ganda yang kontradiktif dari mereka yang melakukan tindakan itu.

Dalam catatan sejarah korupsi di China bukanlah masalah yang baru dan jejaknya dapat ditelusuri sejak zaman kekaisaran. Sejak tahun 1980-an lingkup dan intensitasnya semakin meningkat dalam tingkatan yang belum pernah terjadi sebelumnya. Perdana Menteri Zhao Ziyang (Wang, 1985: 134) menyebut praktek-praktek korupsi yang terjadi di China sebagai kegiatan yang "menjijikkan" di kalangan pejabat, misalnya penyelenggaraan pesta mewah yang berlebihan dengan memperkenalkan para bos/pengusaha, menjajakan pengaruh untuk keuntungan pribadi, dan suap menyuap. Kegiatan korupsi ini sering dikaitkan dengan tradisi guanxi (koneksi). Guanxi merupakan hubungan antar individu yang didasari oleh kepercayaan dan merupakan factor penentu kunci keberhasilan bisnis. Selama periode sembilan bulan tercatat 136.000 kejahatan ekonomi yang dilakukan oleh partai dan kader-kader pemerintah.

Tulisan berikut ini akan mencoba untuk meninjau korupsi di China dari perspektif sejarahnya dengan mencoba melihat masalah dan dinamika pemberantasannya.

\section{B. Masa Kekaisaran}

Dalam sejarahnya, korupsi yang berlangsung di China telah berakar sejak ribuan tahun yang lalu. Hal ini bahkan terlihat dalam setiap proses pergantian kekuasaan dinasti di China sehingga membentuk sebuah pola yang selanjutnya disebut sebagai teori siklus dinasti di China (John K Fairbank, 1973). Awal sebuah dinasti dimulai dengan sebuah periode kepahlawanan yaitu munculnya pahlawan yang berhasil menumbangkan rezim sebelumnya yang menyengsarakan rakyat. Dinasti baru ini kemudian mampu membawa kekaisarannya mencapai puncak kejayaannya. Periode berikutnya adalah periode kemerosotan dinasti dan akhirnya periode keruntuhan. Pada umumnya penguasa terakhir muncul dalam kemewahan dan intrik-intrik istana yang membuat kekuasaan melemah, misalnya korupsi-korupsi di kalangan pengumpul pajak atau praktek suap di bagian kepegawaian.

Dalam periode kemakmuran memunculkan kedamaian. Populasi meningkat dengan cepat, lumbung-lumbung dan harta pemerintah pusat menjadi penuh. Dengan kelebihan itu pemerintah pusat membangun istana mewah, jalan raya, kanal-kanal, dan tembok pertahanan. Penambahan pertahanan militer yang dibentuk pemerintah sangat memakan biaya. Klan kekaisaran, bangsawan, dan pejabat tinggi terus bertambah banyak dan terbiasa dengan gaya hidup mewah. Banyak tanah dan petani penggarapnya yang digunakan untuk kepentingan pribadi klas penguasa dan hanya sedikit yang 
membayar pajak pada pemerintah pusat. Pengeluaran pemerintah terus meningkat secara konstan sementara pendapatannya kecil, sehingga setiap dinasti mulai mengalami kesulitan keuangan yang serius dalam masa-masa pembangunannya.

Kesulitan ekonomi dan pemerintahan semakin terakumulasi. Salah satu penyebab dari periode kemerosotan adalah korupsi di kalangan keluarga istana maupun pejabat istana seperti menteri dan gubernur, juga pegawai-pegawai sampai jauh ke desa-desa. Korupsi yang semakin hebat menyebabkan kemerosotan efisiensi pemerintahan dan semakin meningkatkan perselisihan faksional di istana. Untuk menghadapi defisit keuangan, pemerintah menaikkan pajak para petani. Karena kesulitan keuangan, proyek pembangunan tidak terselesaikan, kanal-kanal atau saluran air dibiarkan terbengkelai menyebabkan banjir atau kekeringan. Kegagalan panen yang dulunya dapat ditangani dengan lumbung-lumbung persediaan milik pemerintah, sekarang menyebabkan kelaparan, yang kemudian menyebabkan munculnya perbanditan dan akhirnya pemberontakan petani.

Kasus-kasus korupsi yang banyak tercatat dalam sejarah China adalah korupsi yang dilakukan oleh kasim istana. Para kasim istana bertugas melayani selir kaisar dan memimpin urusan rumah tangga. Mereka biasanya banyak mengetahui rahasia dalam istana. Fungsi mereka juga menyebar ke bidang lain termasuk kemiliteran. Kaisar dimabukkan dengan segala kenikmatan yang sengaja diciptakan oleh kasim sehingga kasim dapat berlaku sebagai penguasa. Korupsi menyebabkan kemerosotan efisiensi pemerintahan. Pada umumnya hukuman bagi para pelaku korupsi adalah dipecat dari jabatannya dan sanksi hukuman penjara.

Pada masa-masa akhir kekuasaan Dinasti Ming, dalam kekaisaran sendiri terjadi pertikaian karena kekuasaan kasim semakin besar. Para sarjana mantan pejabat menekankan pentingnya integritas moral dan mencela para pemegang kekuasaan. Salah satu tokoh anti korupsi yang sangat terkemuka adalah Hai Rui, seorang guru konfusian muslim yang hidup pada masa pemerintahan dinasti Ming. Ia banyak menyerukan tentang ketidakadilan dan korupsi yang marak terjadi di jajaran pemerintahan. Salah satunya adalah korupsi yang dilakukan oleh kasim Wei Chung-hsien selain berbagai kasus kejahatan lain yang dilakukannya. Tetapi kasim tersebut berhasil menyingkirkannya sehingga ia dipecat dari jabatannya sebagai seorang mandarin dan dihukum. Namun demikian degradasi moral terus terjadi dalam rezim Ming.

Awal dari keruntuhan dinasti Ching, dinasti terakhir dalam sejarah kekaisaran di China, salah satunya juga ditandai dengan maraknya korupsi dalam birokrasi puncak. Kasim Ho-shen yang mendapat kepercayaan dari Kaisar Ch'ieng Lung untuk memimpin bagian pendapatan dan kepegawaian 
bersekongkol dengan jenderal Fu-k'ang-an melakukan korupsi dana operasi militer. Akibatnya kemiliteran Manchu mengalami kemerosotan.

Masa Pemerintahan Republik China

Setelah melalui periode revolusi nasional akhirnya Republik China yang nasionalis berdiri pada tahun 1912, mengakhiri era kekaisaran di China yang telah berlangsung ribuan tahun. Namun China kembali memasuki periode kekacauan yang ditandai dengan munculnya era warlordisme sejak wafatnya Yuan Shi kai (1916) sampai dengan dapat dipersatukannya kembali oleh Chiang Kai Shek (1928). Sejak itu Republik China kembali ke tangan kaum nasionalis (Kuomintang) di bawah pimpinan Chiang.

Pada masa ini pun korupsi terus berlangsung, dan bahkan telah menjadi epidemi pada masa pemerintahan nasionalis. Korupsi merajalela di manamana, memaksa Chiang Kai Shek membentuk badan khusus untuk memeranginya. Badan itu dinamakan 'Kelompok Penumpas Harimau', karena rakyat membandingkan para pejabat yang korup dengan harimau yang buas. Badan itu mempersilakan rakyat untuk mengajukan keluhan. Tetapi kemudian ternyata bahwa sesungguhnya badan itu justru dijadikan sebagai alat oleh mereka yang benar-benar mempunyai kekuasaan untuk memeras uang dari orang-orang kaya. Bahkan 'menumpas harimau' kemudian menjadi pekerjaan yang menguntungkan (Jung Chang, 2005:80).

Bentuk-bentuk korupsi yang umumnya terjadi di kalangan masyarakat, di antaranya adalah pemerasan secara terang-terangan. Apabila permintaan tersebut ditolak maka dianggap sebagai penentang Kuomintang dan akan langsung dituduh sebagai komunis, dan hal itu berarti ditangkap dan disiksa. Para petani enggan menjual hasil bumi ke kota karena mereka harus melewati pos-pos pemeriksaan Kuomintang dan dipaksa membayar uang sogokan atau menyerahkan barang dagangan.

Bahkan Chiang Kai Shek dan keluarganya terlibat erat dalam korupsi, demikian pula pejabat dari tingkat pusat hingga daerah dan para jenderalnya (Lidya Christin Sinaga: http://www.politik.lipi.go.id/index.php/in/kolom/110.) Korupsi ditengarai menjadi salah satu penyebab jatuhnya Kuomintang, antara lain dana-dana bantuan milliter dari Amerika Serikat yang diselewengkan untuk kepentingan pribadi atau kelompok.

\section{Masa Pemerintahan Republik Rakyat China}

\section{Era Mao Tse Tung}

Pada era pemerintahan Mao Tse Tung (1949-1976) kasus-kasus korupsi tidak menghilang begitu saja. Tidak lama setelah merebut kekuasaan, Komunis menghadapi krisis. Mereka berhasil menarik simpati dan mendapat dukungan jutaan rakyat dengan menjanjikan pemerintahan yang bersih, tetapi beberapa 
pejabat mulai menerima suap atau mendahulukan kepentingan kerabat dan teman-teman mereka. Beberapa pejabat mulai suka menyelenggarakan pesta mewah, sebagai suatu kebiasaan yang mendarah daging dalam tradisi China dan merupakan cara untuk menyenang-nyenangkan orang lain sambil pamer, atas biaya dan atas nama negara (Jung Chang, 2005: 193). Banyak pejabat melakukan penggelapan besar-besaran, sementara pemerintah sedang berusaha memperbaiki kondisi ekonomi yang carut-marut.

Mao segera melakukan gerakan-gerakan untuk membersihkan China dari korupsi dengan kampanye-kampanye yang bertujuan untuk membersihkan kelas kapitalis dan menciptakan masyarakat komunis, antara lain gerakan tiga anti (san fan) dan lima anti (wu fan) (Maurice Meisner, 1999: 85-87). Pada akhir tahun 1951 dilaksanakan kampanye tiga anti yaitu pencurian, pemborosan dan birokratisme. Sanfan merupakan kampanye melawan korupsi dan inefisiensi birokrasi. Gerakan ini terutama ditujukan kepada kader-kader kota yang korup, lebih-lebih yang berkecimpung di departemen keuangan dan ekonomi. Tujuannya untuk menakut-nakuti siapa saja yang mempunyai akses ke uang pemerintah agar tidak korup. Pemerintah menghukum mati, memenjarakan dan memecat pejabat-pejabat yang melakukan korupsi. Mereka yang dituduh menggelapkan uang dijuluki 'macan'. Bagi mereka yang menggelapkan uang lebih dari 10.000 yuan adalah macan besar dan pantas mendapatkan hukuman mati (Jung Chang, 2007:427).

Pada bulan Januari 1952 diberlakukan Gerakan Lima Anti (wu fan) yang ditujukan kepada golongan masyarakat yang lebih luas terutama kaum kapitalis, pengusaha-pengusaha swasta yang propertinya belum disita untuk memaksa mereka mengeluarkan uang dalam jumlah yang besar dan menakuti mereka dengan tuduhan melakukan suap dan menghindari pajak. Gerakan ini ditujukan untuk menumpas lima macam kejahatan: suap-menyuap, tidak membayar pajak, pencurian uang negara, menipu kontrak dengan pemerintah dan mencuri informasi ekonomi milik negara. Sejak kedua kampanye itu sangat sedikit orang yang berani menggerogoti uang negara.

Kedua gerakan anti korupsi ini merupakan mekanisme kontrol yang dikembangkan partai komunis, dan merupakan kampanye massa yang dipimpin oleh badan-badan yang disebut tim kerja. Anggotanya terutama pegawai kantor-kantor pemerintah yang dipimpin oleh seorang pejabat senior partai. Dalam setiap kampanye orang yang tergolong dalam kategori 'sasaran Peking' akan terus-menerus diawasi umumnya oleh teman-teman sekerja dan tetangganya, dengan demikian melibatkan seluruh rakyat dalam mekanisme pengawasan. Sedikit sekali orang yang menurut kriteria rezim berbuat kesalahan dapat menghindar dari pengawasan rakyat, terutama dalam masyarakat yang selama berabad-abad terbiasa diatur dan diawasi. 
Pada pertengahan 1953 pelaksanaan Kampanye Tiga Anti dan Kampanye Lima Anti mulai mengendur. Kaum kapitalis habis ditumpas, begitu pula orang-orang Kuomintang. Kampanye ini juga banyak membawa korban orang-orang yang tidak bersalah karena kampanye dilaksanakan berdasarkan kriteria yang tidak jelas dan dendam pribadi, bahkan gossip pun dapat dijadikan sebagai dasarnya (Jung Chang, 196). Pemerintah komunis Mao pada akhirnya memang tidak korup dalam pengertian konvensional, misalnya tidak menerima suap tetapi para pejabatnya diberi hak untuk menikmati standar hidup yang khusus dengan perbedaan berjenjang yang mendetail.

\section{Era Deng Xiao Ping}

Pada era reformasi yang dimulai sejak pemerintahan Deng, korupsi telah dilihat sebagai sesuatu yang berbahaya bagi kelangsungan kekuasaan sehingga banyak kebijakan yang dikeluarkan terkait dengan upaya pemberantasan korupsi. Terlebih sejak dimulainya reformasi ekonomi wabah korupsi semakin marak di China. Lu (dalam I Wibowo, 2004:176) telah mengidentifikasi dan membuat peta wilayah korupsi yang dilakukan oleh pejabat atau kader partai. Korupsi tersebut semakin meluas di berbagai aspek kehidupan dan meningkat intensitasnya dengan berlangsungnya ekonomi pasar pada tahun 1980-an. Misalnya korupsi memperebutkan jatah apartemen tempat tinggal, korupsi dalam perbankan dan keuangan, korupsi dalam penarikan pajak, korupsi dalam law inforcement, korupsi dalam penerapan UU Keluarga Berencana, dan korupsi dalam memperjualbelikan jabatan. Perilaku tersebut merupakan kejahatan ekonomi yang dilakukan oleh kader di setiap tingkatan.

Slogan yang sangat terkenal pada masa pemerintahan Deng Xiao Ping bahwa getting rich is glorious atau menjadi kaya itu mulia, berpengaruh bagi masyarakat China dalam mengumpulkan uang sebanyak-banyaknya. Masyarakat didorong untuk mengejar kemakmuran pribadi. Seruan Deng itu telah memberi rakyat China ruang terbuka yang luas untuk memaksimalkan upaya menjadi kaya. Dalam kenyataannya, di banyak kasus seruan 'menjadi kaya itu mulia' dimaknai dan diterapkan secara negatif sehingga korupsi di China semakin meluas.

Reformasi ekonomi memberikan motif dan kesempatan bagi banyak orang khususnya para pejabat yang paling diuntungkan dengan adanya reformasi, untuk memperkaya diri secara tidak sah. Motif-motif korupsi yang paling menonjol sangat berkaitan erat dengan tradisi guanxi (koneksi) yang telah berakar sangat dalam. Tanpa guanxi bisnis tidak akan berjalan dan seseorang hampir pasti tidak akan mendapatkan apa yang dikehendakinya. Suap menyuap ataupun lewat "jalan belakang" merupakan praktek-praktek yang biasa dilakukan (Wang, 1985: 134). Hal ini semakin kuat ketika pandangan tentang uang berubah di China. Peraturan dan perundang-undangan 
dibelokkan sehingga korupsi semakin meluas, penggunaan suap, sikap pilih bulu untuk mendapat barang-barang yang langka atau mendapatkan sesuatu melalui jalan belakang, maupun pemberian hadiah menjadi hal yang umum. Anak keturunan kader partai tertinggi dan kader pemerintah sering bertindak sebagai "koneksi" atau penghubung bagi pengusaha asing yang menginginkan hubungan dagang yang mapan dengan China.

Deng Xiao Ping memberikan perhatian serius pada pemberantasan korupsi dengan menyampaikan kritik atas lunaknya penanganan pelaku tindak korupsi yang disebutnya melakukan kejahatan ekonomi. Aparat yang berkepentingan dianggap tidak berani bertindak tegas, adanya mentalitas ragu dalam mengambil tindakan justru akan merugikan reformasi ekonomi yang sedang berlangsung. Oleh karena itu perlu dilakukan tindakan keras terhadap pelaku kejahatan ekonomi. Berbagai kebijakan untuk memerangi korupsi antara lain pada tahun 1982 PKC mengeluarkan dekrit dan keputusan "Resolusi Menghancurkan Kejahatan Ekonomi”, kampanye tahun 1980-1981 "Kampanye mengurangi Privilese para Pejabat dan Tendensi Tidak Sehat dalam Partai”, tahun 1982 "Kampanye Menghancurkan kejahatan Ekonomi, tahun 1983 "Kampanye Menghapuskan Ketidakberesan oleh Pejabat dalam Pembagian Perumahan", tahun 1984-1985 "Kampanye Menghentikan Pejabat masuk dalam Kegiatan Perdagangan", tahun 1986-1987 "Kampanye Menghukum Pelanggaran Undang-undang dan Disiplin Partai maupun Negara”, tahun 19881989 "Kampanye Membangun Pemerintah yang Bersih dan Mencegah Korupsi” (I Wibowo, 2004:178). Berbagai kebijakan yang dikeluarkan mengindikasikan banyaknya kejahatan korupsi yang terjadi di China saat itu.

\section{Pasca Pemerintahan Deng Xiao Ping}

Komitmen kuat penguasa China untuk memberantas korupsi sudah dimulai sejak masa Zhu Rongji (1997-2002). Ucapannya yang sangat terkenal adalah "Beri saya 100 peti mati, Sembilan puluh sembilan akan saya gunakan untuk mengubur para koruptor, dan satu untuk saya kalau saya melakukan tindakan korupsi." Pemberantasan korupsi yang dilakukan Perdana Menteri China itu merupakan bagian dari reformasi birokrasi. Langkah ini memberikan kepastian hukum sehingga mampu menghimpun dana asing senilai 50 miliar dollar AS setiap tahun. Pertumbuhan ekonominya langsung melesat, terlepas

dari kelemahannya. Bentuk keseriusan pemerintah China dalam pemberantasan korupsi salah satunya juga diwujudkan dengan ikut meratifikasi Konvensi PBB melawan korupsi yang memasukkan suap kepada pejabat publik sebagai tindak kriminal oleh Kongres Rakyat Nasional pada bulan Oktober 2005.

Kitab Undang-undang Hukum Pidana (KUHP) China mengatur mereka yang menawarkan dan menerima suap bisa dihukum. Hukuman mati bagi 
penerima suap dan hukuman seumur hidup bagi pemberi suap.Hukuman mati merupakan hukuman terberat yang dapat diberikan kepada koruptor. Hukuman mati ini juga diterapkan kepada pejabat tinggi negara, bukan hanya kepada pejabat rendah atau orang-orang biasa. Beberapa pejabat yang divonis mati karena korupsi antara lain Cheng Kejie, (Ketua Pemerintah Daerah Otonom Guangxi), Ma Xiangdong (Wali Kota Shenyang), Li Jiating (Gubernur Yunnan), Ma De (Sekretaris PKC Komite Kota Suihua, Heilongjiang), dan Liu Jinbao (Direktut Utama Bank of China di Hongkong). Pemerintah China menunjukkan keseriusan dalam memberantas korupsi. Pemerintah China bertekad secara konsisten mengawal pembangunan ekonomi dengan menekan sekecil mungkin penyalahgunaan wewenang dalam tubuh birokrasi.

Bagi pemerintah China komunis, perang melawan korupsi merupakan suatu keharusan yang wajib dijalankan. China ingin menunjukkan kepada dunia bahwa ideologi komunisme yang mereka anut bukan merupakan halangan untuk mencapai kemakmuran ekonomi, pemerintahan yang bersih, dan masyarakat yang beretos kerja dan berdisiplin tinggi. Dalam hal ini China menumpukan upaya-upaya pemberantasan korupsi pada Partai Komunis China (PKC), partai berkuasa di China. China memberikan contoh bagaimana partai politik harus berperan utama dalam pemberantasan korupsi dengan menanamkan disiplin anti korupsi yang kuat pada semua anggotanya.

Upaya pemberantasan korupsi di China yang begitu keras dapat dilihat langsung dari banyaknya koruptor yang dihukum mati di negara tersebut. Bila bukan hukuman mati, hukuman penjara ataupun hukuman ganti rugi yang diberikan sangat berat. Hal ini dimaksudkan untuk menumbuhkan efek jera dan takut korupsi. Selama tahun 2009 lebih dari 106.000 pejabat pemerintah di China telah dikenai hukuman terkait dengan masalah korupsi (Kompas, 8 April 2010). Pada awal tahun 2010, PKC menegaskan aturan baru untuk seluruh kadernya yang sebenarnya telah diberlakukan sejak tahun 2006, yaitu kewajiban bagi seluruh anggota PKC untuk melaporkan harta kekayaan keluarganya. Sebelumnya kewajiban melaporkan itu hanya dikenakan kepada mereka yang menjabat di pemerintahan dan pengurus PKC, maka kebijakan baru diberlakukan untuk seluruh anggota PKC di semua tingkatan. Melalui aturan ini setiap anggota PKC harus juga melaporkan kekayaan istri/suami dan anak-anaknya. Organ disiplin PKC pun akan terus mengatur pengeluaran pemerintah terkait dengan pembelian kendaraan, resepsi di kantor-kantor pemerintah, dan juga perjalanan-perjalanan keluar negeri untuk memastikan uang pembayar pajak digunakan dengan bijak. Situasi korupsi di China yang belum menunjukkan tanda-tanda mulai mereda, yang juga terlihat dari Indeks Persepsi Korupsi yang dikeluarkan oleh Transparansi Internasional yang menempatkan China di posisi ke-72 dari 180 negara yang disurvei. Oleh karena itu China terus menyempurnakan sistem deklarasi asset seluruh pekerja 
pemerintah sebagai salah satu cara agar rakyat semakin aktif mengontrol praktek korupsi.

\section{E. Penutup}

Korupsi bukan merupakan suatu hal yang baru di China, melainkan telah ada sejak ratusan bahkan ribuan tahun sebelum masehi. Para kasim istana merupakan kelompok yang banyak tercatat dalam sejarah sebagai pelaku tindak korupsi. Pada masa ini hukuman berupa pemecatan dari jabatan dan hukuman penjara merupakan hal yang lazim dilakukan. Selanjutnya pada masa pemerintahan nasionalis China di bawah kepemimpinan Chiang Kai Shek dikenali sebagai pemerintahan yang sangat korup, bahkan korupsi ini ditengarai sebagai salah satu penyebab jatuhnya pemerintahan Chiang.

Upaya pemberantasan korupsi pada masa pemerintahan Mao Tse Tung dilakukan melalui gerakan-gerakan kampanye secara radikal. Kebijakan Mao ini cukup berhasil menekan jumlah kader partai dan pemerintahan melakukan korupsi, meskipun dalam kenyataannya para petinggi partai menikmati keistimewaan tersendiri. Pada era Deng Xiao Ping dengan diberlakukannya politik pintu terbuka dalam rangka reformasi ekonomi telah membawa ekses pada meningkatnya tindak korupsi di China. Hal ini tidak terlepas dari tradisi guanxi.

Pemerintah China sangat sadar akan bahaya korupsi bagi kejatuhan rezim sehingga berupaya keras untuk memberantasnya. Meskipun belum sepenuhnya berhasil menghapuskan korupsi di China, tetapi apa yang dilakukan oleh pemerintah China dianggap cukup berhasil menurunkan indeks korupsi di China. Akankah Indonesia belajar dari China?

\section{Daftar Pustaka}

Bagus Dharmawan (ed.), Cermin dari China: Geliat Sang Naga di Era Globalisasi, Jakarta: Penerbit Buku Kompas, 2006.

Endang Retnowati, "Korupsi: Kejahatan yang Tersistem", Masyarakat Indonesia, Jilid XXXV, no. 1, 2009, hlm. 135-155.

Fairbank, John King, East Asia: Tradition and Transformation, London: George Allen \& Unwin, 1973.

Ignatius Wibowo, Negara dan Masyarakat: Berkaca dari Pengalaman Republik Rakyat Cina, Jakarta: Gramedia Pustaka Utama, 2000. , Belajar Dari China: Bagaimana China Merebut Peluang Dalam Era Globalisasi, Jakarta: Penerbit Buku Kompas, 2004.

Jung Chang, Angsa-Angsa Liar: Tiga Putri China, terj. Honggo Wibisono, Jakarta: Gramedia Pustaka Utama, 2005.

Jung Chang dan Jon Halliday, Mao: Kisah-Kisah yang Tak Diketahui, Jakarta: Gramedia Pustaka Utama, 2007. 
Lidya Christin Sinaga, "Wajah Korupsi di China", dalam http://www.politik.lipi.go.id/index.php/in/kolom/110.

Kompas, "Partai Berperan Kunci Perangi Korupsi”, 8 April 2010.

Meisner, Maurice J., Mao's China and After: A History of the People's Republic, New York: The Free Press, 1999.

Taufik Adi Susilo, China Connection, Jogjakarta: Garasi, 2008.

Wang, James CF., Contemporary Chinese Politics: An Introduction, New Jersey: Prentice Hall, 1985.

Biodata Penulis: Ririn Darini adalah staf pengajar pada jurusan Pendidikan Sejarah FISE UNY. Menyelesaikan S1 Sejarah UGM tahun 1998 dan S2 Sejarah UGM tahun 2004. Saat ini mengampu mata kuliah Sejarah Asia Timur. 